
\begin{tabular}{ll}
\hline Elfving, F. (84) * * Öfversigt af Finska Vetenskaps Förhandlingar, \\
r884. \\
Giesenhagen, K. (or) \\
Ueber innere Vorgänge bei der geotropischen \\
Krümmungen der Wurzeln von Lhara. Ber.
\end{tabular} Krümmungen der Wurzeln von Lhara. Ber.

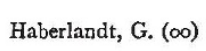
Deber Ber. D. Bot. Gesell. r 8 . Bd. r9oo, p. $26 \mathrm{r}$. mechanischer Reize. Leipzig (Engelmann),

(o2) - Ueber die Statolitbenfunction der Stärkekörner. Ber. D. Botan. Gesellsch. 20. Bd. 1902, p. 389

"

(.03) ur Statolithen heorie des Geotropismus. p. bücher für wiss. Bot. 38 . Bd. 1903, p. 447 .
Ueber die physiologische Function der Stärke

Heine, H. $\left(8_{5}\right)$ scheide. Ber. d. Deutschen Bot. Gesellschaft. 3. Bd. 1885 , p. 189 .

Jost, L. (or) . . . Ueber einige Eigenthümlichkeiten des Cambiums der Bäume. Bot. Zeitung (Abt. i.), rgor, p. I. der Baume. Bot. Zeitung (Abt. 1.), rgor, p. I. Die Perception des Schwerereizes in der Pflanze. Biolog. Centralblatt, 22. Bd. Mär. 1902, p. 16r. Weitere Beiträge zur Physiologie des Ohrlaby-
rinthes (ii.). Versuche an Krebsen. Sitzb. d. Wiener Akad. d. Wissensch. 102. Bd. 1893 .

Kreidl, A. (93)

Meischke, P. (99) . Ueber die Arbeitsleistung bei der geotropisch Krümmung. Jahrb. für wiss. Bot. 33. Bd. 1899,

Miehe, H. (o2) - . Ueber correlative Beeinflussung des Geotropismus einiger Gelenkpflanzen. Jahrbüche für wiss. Bot. 37 . Bd. 1902, p. 527

Němec, B. $(\infty) \quad$. Ueber die Art der Wahrnehmung des Schwerkraftreizes bei den Pflanzen. Ber. D. Botan Gesellsch. 18. Bd. 1900, p. 24 1.

(or) . Ueber die Wahrnehmung des Schwerkraftreizes bei den Pflanzen. Jahrbücher für wiss. Bot. 36. Bd. Igor.

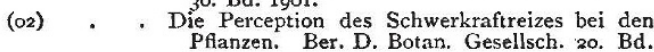
1902, p. 339. (o4) - Einiges uber den Geotropismus der WurzeIn

Noll, F. (88) . . . Sachs' Arbeiten, vol. iii. 1888, p. 466.

Ueber Heterogene Induktion, Versuch eines Beitrags zur Kenntniss der Keizerscheinungen der Pflanzen. Leipzig (Engelmann), 1892.

, (92) .

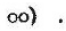
eber Geotropismus. Jahrbiicher für wiss. Bot. 34. Bd. 1900, p. 457.

,$\quad(02)$.

Pertz, D. (99) .

Piccard, A. (04)

Pfeffer, W. (93)

Tondera, M. F. (03)

Zur Controverse über den Geotropismus. Berichte d. Deutschen Bot. Gesellschaft, 20. Bd. rgo2, p. $4^{\circ} 3$

the Gravitation Stimulus in relation to Position. Annals of Botany, 1899, p. 620

Neue Versuche über die geotropische Sensibilität der Wurzelspitze. Jahrbücher für wiss. Bot. 40. Bd. 1904, p. 94

Die Reizbarkeit der Pflanzen. Verhandlungen d. Gesellschaft Deutscher Naturforscher u. Aerzte, ז893.

Pflanzenphysiologie, edit. i. $188 \mathrm{r}$, vol. ii. p. 330 Contributions à la connaissance de la gaine d'amidon. Anzeiger der Akad. d. Wissensch. in Krakau, July rgo3, p. 512.

Vöchting, H. (78) . . Organbildung im Pflanzenreich, $187^{8}$ and 1884 . (92) : : Ueber Transplantation am Pflanzenkörper (T'übingen), 1892 .

Wiesner, J. (o2) • - Studien über den Einfluss der Schwerkraft über Wiener Akad. der Wiss, xx. Bd. I902, p. de

\section{THE SIXTH INTERNATIONAL CONGRESS OF ZOOLOGY.}

THE smoothness with which the complicated arrangements for the reception and housing of so many guests were carried out, and the kindness and hospitality of the welcome extended to them, formed a good augury for the success of the sixth International Congress of Zoology, which opened at Berne on Monday, August i5. On the previous day the members, gathered from many parts of the world, were received by the reception committee at the railway station, and invited afterwards by the Mayor of the city to a "symposium " in the " Kornhauskeller." The gaiety of the assembly, which did not break up until a late hour, formed an agreeable prelude to the work of the congress, which was throughout interspersed with pleasant entertainments.

At the general meeting the next morning Prof. Studer, the president, chose as the subject of his address the Swiss fauna, to the study of which he has devoted so much of his life. Prof. Perrier, of Paris, as president of the permanent committee, thereupon expressed his feelings of gratitude to the Swiss Government and to the authorities of the canton of Berne for the hospitality which had been extended to the members of the congress. The following gentlemen, Profs. Studer, Minot, Grassi, and Perrier, were afterwards elected presidents for the general meetings, and Profs. Emery, Fujii, Spengel, Osborn, v. Graff, Pelseneer, Lönnberg, Blanchard, Chun, v. Wijhe, Lang, and Drs. Horvath, Stejneger, Stiles, and Miller as vice-presidents. The meeting also agreed to divide into seven sections, viz. :General Zoology, president, Prof. Salensky; vice-president, Mr. Schlumberger; secretary, Dr. Gurwitsch. Vertebrata (systematic), president, Dr. Jentink; vice-president, Dr. Scharff; secretary, Dr. André. Vertebrata (anatomy, \&c.), president, Prof. Monticelli; vice-president, Dr. Bashford Dean; secretary, Dr. Penard. Invertebrata (excluding Arthropoda), president, Prof. Ehlers; vice-president, Prof. Koehler; secretary, Dr. Fuhrmann. Arthropoda, president, Prof. Heymons; vice-president, Dr. Janet; secretary, Dr. Steck. Applied Zoology, president, Prof. Hoek; vice-president, Prof. Plate; secretary, Dr. Duerst. Zoogeography, president, Prof. Hérouard; vice-president, Prof. Blasius : secretary, Dr. Roux.

Two propositions had been received by the president, Prof. Studer, one from the Prince of Monaco, to hold the next congress at Monaco, and another from the zoologists of the United States of America. After due consideration of these proposals, it was decided by the permanent committee and by the delegates of the scientific societies to recommend that the latter invitation be accepted, which was unanimously adopted at the general meeting. It was therefore agreed that the next congress, in 1907, should be held at Boston, and that Prof. Agassiz be asked to preside. Prof. Minot expressed the hope that it might be possible to place at the disposal of the European zoologists a large steamer, which would call for them at Hamburg, Cherbourg, and Southampton.

Subsequently, Prof. Blanchard gave an interesting address on the production of disease in man by animal parasites, and also pointed out in how many ways zoological discoveries had aided not only the elucidation and diagnosis of disease, but also its cure; after which Prof. Lang made some remarks on the life of the Swiss naturalist, Alexander Morizi, born in 1806 at Chur, who, some years before the appearance of Darwin's "Origin of Species," had published a paper in which he promulgated the theory of evolution and supported the view that man had evolved from the higher animals.

At one of the later general meetings, Profs. Salensky, Osborn, Chun, Hoek, and Sarasin delivered addresses. Prof, Salensky referred to the results of the most recent investigations of the life-history and anatomy of the mammoth, and exhibited photographs of a specimen in situ (already noticed in NATURE), as well as preparations of the skin, muscles, hairs, \&c. It seems now to be a well established fact that the mammoth was a northern species feeding especially on conifers, but also on cyperaceous, graminaceous, and leguminous plants. The recently discovered stages in the evolution of the horse and contemporary mammals in North America formed the subject of Prof. Osborn's lecture, while Prof. Chun dealt with the vertical distribution of the marine plankton.

Altogether more than four hundred zoologists, many of whom brought one or more members of their family, took part in the congress. The general meetings were held in the large hall of the Swiss House of Parliament, and the sections met in the lecture rooms of the splendid university buildings, of which the country is justly proud.

\section{I.--General Zoology.}

It has been assumed that the South American Stegomyia was the means of transferring a blood parasite to man, which gave rise to yellow fever; Prof. Goeldi, of Para, however, gave reasons for his belief that this disease is not due to any blood parasite, but to an organic toxin which he discovered in the saliva of Stegomyia.

The zoological aspect of De Vries's mutation theory was discussed by Prof. Plate, who recognised that the theory signified an important advance of knowledge in so far as it showed that sudden changes could arise in the organism which were highly transmissible, but he urged that a sharp morphological boundary could not be drawn between variations and mutations. The former must be considered as changes with a slight capacity of inheritance, the latter as such with a high capacity.

No. I8I9, vol. 70] 
As the result of anatomical investigations in butterflies, Mr. Petersen, of Reval, attempted to show that all species can be distinguished morphologically by their reproductive organs, and that it is through physiological isolation that varieties form the starting point for new species.

Prof. Maas reviewed the experiments he had carried out in depriving young sponges of carbonate of lime before their metamorphosis.

Prof. Vejdovski demonstrated the presence of a nucleus in Bacterium Gammari, already described (cf. Centralblatt f. Bakteriologie, I90I and 1904), while Prof. Looss, of Cairo, indicated how the larvæ of Ancylostomum and Strongyloides migrate through the hair-follicles of the human hand into lymph- or blood-vessels, and from there reach the intestine by way of the heart, lungs, and air passages.

\section{II.-Vertebrata. (Systematic).}

Several papers of particular interest were discussed in this section. Among these may be mentioned that of Prof. Scott, of Princeton, on the Miocene mammals of Patagonia. He referred to the fact that the fossil rodents all belong to the Histricomorpha, of which South America is still the headquarters. The Edentata are represented by the three orders Gravigrada, Dasypoda, and Glyptodontia. Several orders of ungulates, he remarked, displayed striking similarities to northern orders, but these similarities must be looked upon as convergent developments, and not due to a common descent.

Mr. Bieler, of Lausanne, described the skull of an extremely small bear obtained in the Alps some years ago, which he identified as belonging to Ursus formicarius.

An artificially produced hybrid between Triton cristatus and T. marmoratus was exhibited by Dr. Wolterstorff, who remarked on its identity with Triton Blasii.

Mr. Borodine, of St. Petersburg, described the herrings of the Caspian, in which sea he was able to distinguish no less than five species, three of which were essentially marine forms.

Recent studies and discoveries in the evolution of the horse, with lantern demonstrations, formed the subject of an interesting lecture by Prof. Osborn, who mentioned that more than a hundred more or less complete skeletons of horses and horse-like animals had been found fossil in North America. He thought he had established the fact that horses were polyphyletic, there being four or five contemporary series in the Miocene, but that the direct origin of the genus Equus in North America was not established with certainty.

Prof. von Méhely's paper dealt with the skull and dentition of the species of Spalax, a small East European rodent. As the result of his careful investigations he was able not only to demonstrate that the twelve species described hitherto could be reduced to three, but that the origin of the latter was clearly traceable from an extinct form by gradual mutations, due chiefly to selection.

Prof. Tornier dwelt on the subject of the origin and significance of the coloration of the skin in reptiles, and attempted to demonstrate that those parts which were folded during the animals' movements were less well nourished than the remaining parts, and were therefore lighter in colour.

\section{III.-Vertebrata (Anatomy and Embryology).}

Dr. Kerbert referred to the fact that the giant salamanders of Japan in the aquarium at Amsterdam had produced young, and described the eggs of the species; while Dr. Bashford Dean, of New York, pointed out the peculiarities in the development of Chimaera Collici.

The specimens of Ceratodus brought back from Australia by the Semon Expedition enabled Prof. Burckhardt, of Basle, to undertake some anatomical investigation of its central nervous system, of which the author exhibited illustrations and models, and he also showed some reconstructions of fossil vertebrates not hitherto figured.

Prof: van Wijhe, of Groningen, gave a demonstration on the development of the skull in elasmobranchs, while Prof. Lönnberg, of Stockholm, exhibited a fœtal Elephas cyclotis, and made some remarks on the homologies of the avian bill.

Dr. Helbing, of Basle, communicated the results of his No. I 8 [9, VOL. 70] investigations on the anatomy of Læmargus, and Mr. Bles spoke on the hatching of Anuran tadpoles and the function of Kupfer's "Stirnknospe." He also exhibited Prof. Kerr's slides of the early development of the motor nerve trunks in Lepidosiren paradoxa.

\section{IV.-Invertebrata (exclusive of Arthropoda).}

Prof. Meyer, of Kasan, described the primitive ambulacral system in Echinoderms, and the diaphragm-sacs which serve to swell the head tentacles in terrebelloid annelids, and discussed the theoretical bearings resulting from a comparison of these somewhat similar structures.

Prof. Salensky gave an account of the prototroch, and also referred to the formation of cœlomesoblast of the larva of Echiurus, while the morphology of the cardial organs of Appendicularia formed the subject of another of his papers.

A description of the mode of nutrition of the embryos of Purpura was then given by Prof. Pelseneer. It appears that the majority of the ova undergo an irregular segmentation and form a vitelline mass, on which a few embryos fix themselves and absorb it completely.

Profs. Caullery and Mesnil exhibited preparations of two cœlomic annelid parasites. The first of these, Pelmatosphaera polycirri, forming numerous spheres, is allied to the Orthonectida, and lives in the general body-cavity of the host. The next, Sphaeractinomyxon Stolei, is the first marine representative of the Actinomyxidæ, and inhabits marine Oligochæts.

Prof. Fuhrmann, of Neuchâtel, described the three known species of Cestodes in which the sexes are in distinct individuals, and which are characterised by very marked dimorphism.

It was urged by Prof. Monticelli, of Naples, that the Temnocephala, for which he proposes the name of Dactyloda, should be looked upon as constituting a group distinct from the Platelminthes.

The most exciting exhibition in this section, and, indeed, one of the most fascinating features of the congress, was a kinematograph demonstration of the development of one of the Botryllidæ. These were kept in a flat-sided glass jar to which a constant stream of fresh sea-water was supplied. Taking a series of photographs at certain regular intervals by means of an ingeniously constructed registering camera, Prof. Pizon, of Nantes, succeeded in producing before the audience a continuous and rapid picture of the gradual evolution of the colonies of the Tunicate. Prof. Marey had shown us some years ago how the quick movements of animals such as the horse and the dog could be reduced on the screen to slow motions, while Prof. Pizon now demonstrated how this can be accomplished in a converse manner.

$$
\text { V.-ARTHROPODA. }
$$

Most of the papers in this section dealt with ants. Dr. Forel brought forward some new biological observations, in the course of which he mentioned that there were now about 4000 species known, and 900 varieties; while Prof. Emery discussed the origin of ants' nests; Dr. v. Buttel-Reepen the insect colonies in general; Mr. Pieron the problem of recognition among ants; and Prof. Goeldi, of Para, the mushroom gardens constructed by Atta cephalotes.

A few other papers dealt with Lepidoptera, such as that of the Countess v. Linden on the influence of the withdrawal of oxygen during the pupal stage on the shape of butterflies, and that of $\mathrm{Mr}$. Pictet on variations produced in butterflies by changing the food of their caterpillars and by humidity.

Two communications deserve a special reference, viz. Prof. Blanc's discovery of a Caprellid in the Lake of Geneva, and Prof. Heymons's paper on the development of the Solifuga. Prof. Blanc exhibited a female specimen of an undescribed Podalirius; a marine genus of crustacean, and mentioned that other invertebrates allied to marine forms were known to inhabit the lake. The development of the Solifuga agrees, according to Prof. Heymons, in all important respects with that of the Arachnida, but it offers no clue to any closer relationship with insects, as some authors seem to think.

\section{V.-Applied Zoology.}

Dr. Jentink's discourse on the ideal natural history museum was delivered in this section. The director of the 
Leyden Museum advocates the complete separation of the study and exhibition series, and insists on the great importance of the absolute protection of the specimens from fire, dust, and light.

Prof. Plate described a new microscope suitable for exhibition in museums; Prof. Forel a new method of collecting specimens inhabiting the deep water in lakes; while Prof. Fujii, of Tokyo, referred to some micro-technical apparatus of his own invention.

Finally, a demonstration was given on the installations of the "concilium bibliographicum," by Dr. Field.

\section{VII.-ZOOGEOGRAPHY.}

Mr. Schmidt, of St. Petersburg, explained the distribution of the fishes in the northern Pacific, and mentioned that the northern fauna of Japan should be considered as belonging to the Arctic region, and that the fishes of southern Japan and the west coast of North America are very distinct from those of the northern parts.

Prof. Simroth gave his views on the origin of the Alps, based chiefly on the distribution of the Mollusca. Dr. Pellegrin, of Paris, described the fish-fauna found in Lake Tchad and the Chari River, which he declares to be very similar to that of the Nile.

Prof. Forel gave his experiences on the occurrence of Larus ridibundus on the Lake of Geneva. It appears that thousands of these gulls are present on the shores of the lake during winter, and that they migrate northward in March, to return again in October with their young. A few remain all the year round. The principal lines of migration of birds across Switzerland were then described by Prof. Fatio, of Geneva.

The congress ended with a couple of days of most pleasant social intercourse. The members were afforded an opportunity of seeing the beauties of the Bernese Oberland during an excursion along the Lake of Thun, and an afternoon spent at Interlaken, where a final meeting was held in the "Kursaal." Saturday was devoted to a trip to Geneva, where, after a lunch and a visit to the museums, the venerable Mr. de Saussure entertained the guests at his country seat near the city, and a Venetian fête with fireworks brought the congress to a close.

\section{ROTATION OF SATURN'S RINGS.}

$\mathrm{O}^{\mathrm{N}}$ 1903 November $6,5 \mathrm{~h} .25 \mathrm{~m} .$, I observed a large diffused white' spot a little north-east of the extremity of the western ansa. It was placed on the bright rim of the interior ring, just bordering Cassini's division, and appeared to extend faintly over the outer ring.

November 7 was cloudy, but on November 8 there was a clear sky and pretty good definition, but no certain differences of tint could be remarked in the individual rings.

On November 9, 5 h. rom., the planet was very faint, and the two ansæ seemed equally bright. At 5 h. 5om., however, the western ansa was decidedly the more luminous, and the aspect appeared similar to that on November 6 .

November IO, II, I2, and I3 were cloudy; November I4 was stormy with fine intervals, but definition was very unsteady, and no white spot could be discerned on the rings.

On November is there was a clear, frosty sky. At $5^{\text {h. }} 5 \mathrm{om}$., under good definition, the ring seemed notably brighter on western than on eastern ansa.

On November 16 definition was very bad, ana no details could be satisfactorily made out. November I7 was cloudy.

On November $18,5^{\text {h. }}$ to 5 h. 4 om., there was a good deal of fog, and the planet's image, appeared very faint. The western ansa seemed decidedly brighter than the other, but the luminosity appeared diffused and not caused by a definite spot.

No satisfactory observations were secured after the latter date. The weather was extremely unsettled, and definition generally very bad, so that though the planet was examined, whenever visible, until December II, no further inequalities in the luminosity of the rings were noted.

The bright area seen on November 6 and several other evenings appeared recurrent in same position at intervals of 3 days, whence I infer that the rotation period of the No. I8I9, VOL. $; 0]$ ring is about $14 \mathrm{~h}, 24 \mathrm{~m}$. This determination is, however, extremely rough, and only useful as affording evidence of the approximate value.

After I had arrived at this result, I consulted various authors to find what previous estimates had been made as to the rotation of the rings.

Laplace theoretically computed that the ring ought to rotate in roh. 33m. 36s. (Chambers's "Descriptive Astronomy," third edition, p. 143). In Laplace's "System du Monde," however, it is stated that Saturn rotates in 0.428 day and the ring in 0.437 day, the equivalents being $=$ Ioh. $16 \mathrm{~m} .17 .2 \mathrm{~s}$. and $10 \mathrm{~h} .29 \mathrm{~m}$. $16.8 \mathrm{~s}$.

Sir W. Herschel, from a spot or luminous point seen on the interior ring in July, 1789 , ascertained that the ring revolved round the ball in roh. $32 \mathrm{~m}$. 15.4s. (Phil. Trans., I79o, vol. 1xxx. p. 479).

Secchi obtained many measures of Saturn's system in $1854-6$, and apparently detected an ellipticity in the rings, for the discordances were considerable, and harmonised at intervals of 3 and 9 days. He concluded that a period corresponding to that which a satellite would have if situated on the outer ring, viz.

$$
\text { 14h. } 23 \mathrm{~m} \text {. } 18 \mathrm{~s} \text {, }
$$

would satisfy them (Monthly Notices, vol. xvi. p. 52). The correspondence between Secchi's period and my own roughly ascertained value, being quite independent, is rather singular.

Now that Saturn is very favourably visible, it is to be hoped that observers will frequently examine the rings for differences in tint or tone which may afford material for the rotation period to be re-determined.

\section{W. F. Denning.}

\section{UNIVERSITY AND EDUCATIONAL INTELLIGENCE.}

THE title of professor has been conferred on Dr. Karl Schreber, of Greifswald, for physics, and on Dr. Robert Pschorr, of Berlin, for -chemistry.

Mr. Alexander Lauder, senior demonstrator in chemistry in the University College of North Wales, Bangor, has been appointed lecturer in agricultural chemistry in the Edinburgh and East of Scotland College of Agriculture.

In connection with the technical college which will shortly be proceeded with at Stoke-on-Trent, it is proposed to have a school of pottery, which shall not only train pupils, but also act as a central advisory and analytical department for manufacturers. There will also be a mining department. The estimated cost of the building, some $25,000 l$., has been practically assured, the North Staffordshire Institute of Mining and Mechanical Engineers contributing 4oool, the Staffordshire County Council $4000 l$, the training authority $6000 l$., while close on $10,000 l$. has been promised as voluntary contributions.

Dr. Anton Lampe and Dr. Hans Benndorf, of Vienna, and Dr. F. Streintz, of Graz, have been appointed extraordinary professors of physics. Herr Reinhold Lutz has been appointed professor of mechanical engineering at the Aachen Technical College, Dr. George Schlesinger professor of the theory of mechanical implements in the Berlin Technical College. Dr. Karl Rohn, now professor of geometrical drawing in Dresden, has been appointed professor of mathematics in the University of Leipzig as from April I, 1905. Dr. Ludwig Prandtl, now professor at Hanover, has been appointed to the chair of technical physics and agricultural mechanics at the University of Göttingen.

The calendar for the session 1904-5 of the Merchant Venturers' Technical College, Bristol, indicates several improvements which have been made recently at this institution. Among these may be mentioned the new experimental steam engine, with its boiler and measuring appliances, and the experimental light and power station now in use by the students. The courses for engineering students have been re-arranged, and provision has been made for a fourth year's course in civil, mechanical, and electrical engineering. The staff of the engineering departments has been strengthened by the appointment of an additional lecturer. 